\title{
Neptunium and plutonium complexes with a sterically encumbered triamidoamine (TREN) scaffold
}

DOI:

$10.1039 / \mathrm{c} 6 \mathrm{cc} 01656 \mathrm{a}$

Document Version

Accepted author manuscript

Link to publication record in Manchester Research Explorer

\section{Citation for published version (APA):}

Brown, J. L., Gaunt, A. J., King, D., Liddle, S., Reilly, S. D., Scott, B. L., \& Wooles, A. (2016). Neptunium and plutonium complexes with a sterically encumbered triamidoamine (TREN) scaffold. Chemical Communications, 5428-5431. https://doi.org/10.1039/c6cc01656a

\section{Published in:}

Chemical Communications

\section{Citing this paper}

Please note that where the full-text provided on Manchester Research Explorer is the Author Accepted Manuscript or Proof version this may differ from the final Published version. If citing, it is advised that you check and use the publisher's definitive version.

\section{General rights}

Copyright and moral rights for the publications made accessible in the Research Explorer are retained by the authors and/or other copyright owners and it is a condition of accessing publications that users recognise and abide by the legal requirements associated with these rights.

\section{Takedown policy}

If you believe that this document breaches copyright please refer to the University of Manchester's Takedown Procedures [http://man.ac.uk/04Y6Bo] or contact uml.scholarlycommunications@manchester.ac.uk providing relevant details, so we can investigate your claim.

\section{OPEN ACCESS}




\section{Chemical Communications}

\section{COMMUNICATION}

\section{Neptunium and plutonium complexes with a sterically encumbered triamidoamine (TREN) scaffold}

Received 00th January 20xx Accepted 00th January 20xx

DOI: $10.1039 / x 0 \times x 00000 x$
Jessie L. Brown, ${ }^{a}$ Andrew J. Gaunt, ${ }^{* a}$ David M. King, ${ }^{b}$ Stephen T. Liddle, ${ }^{* b}$ Sean D. Reilly, ${ }^{a}$ Brian L. Scott, ${ }^{c}$ Ashley J. Wooles ${ }^{\mathrm{b}}$

www.rsc.org/

The syntheses and characterisation of isostructural neptunium(IV) and plutonium(IV) complexes $\left[\mathrm{An}^{\mathrm{IV}}\left(\mathrm{TREN}^{\mathrm{TPS}}\right)(\mathrm{Cl})\right][\mathrm{An}=\mathrm{Np}, \mathrm{Pu}$;

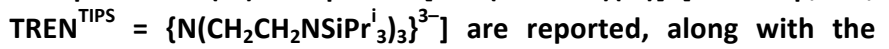
demonstration that they are likely reduced to the corresponding neptunium(III) and plutonium(III) products [An ${ }^{\text {III }}\left(\operatorname{Tren}^{\text {TIPS }}\right)$ ]; this chemistry provides new platforms from which to target a plethora of unprecedented molecular functionalities in transuranic chemistry and the neptunium(IV) molecule is the first structurally characterised neptunium(IV)-amide complex.

Non-aqueous molecular uranium chemistry has flourished in recent years, with the isolation of landmark complexes containing unprecedented actinide-ligand functionalities, ${ }^{1-7}$ with examples including terminal nitride, bis(imido), tris(imido), phosphinidene, arsinidene/arsenido, and terminal chalcogenide moieties. ${ }^{8-19}$ The insight afforded by these studies has profoundly enhanced our understanding of the ability of the valence $5 \mathrm{f}$ and $6 \mathrm{~d}$ orbitals to engage in covalent interactions, which is most readily studied in metal-ligand multiple-bonding interactions. However, uranium is not the only $5 f$ element of practical relevance and it is, perhaps, of more telling impact to decipher covalent bonding trends and redox differences across all of the relevant and synthetically available actinide elements, such as neptunium and plutonium. ${ }^{20-23}$ Due to the specialist radiological facilities required to safely handle the transuranium elements, progress pales compared to uranium.,24 Nonetheless, very recently a neptunium(V)-bis(imido) complex was reported; ${ }^{25}$ this is the first example of a non-dioxo transuranic metal-ligand multiple-bond, suggesting that transuranic elements may also offer a rich reservoir of accessible multiple-bond chemistry.

In order to approach general accessibility of multiply-bonded functionalities systematically, a supporting scaffold to control and direct reactivity at a single coordination site is required. In this

\footnotetext{
a. Chemistry Division, Los Alamos National Laboratory, Los Alamos, New Mexico 87545, USA. E-mail: gaunt@lanl.gov

${ }^{b .}$ School of Chemistry, The University of Manchester, Oxford Road, Manchester M13 9PL, United Kingdom. E-mail: steve.liddle@manchester.ac.uk

c. Materials Physics and Applications Division, Los Alamos National Laboratory, Los Alamos, New Mexico 87545, USA.

† Footnotes relating to the title and/or authors should appear here. Electronic Supplementary Information (ESI) available: [details of any supplementary information available should be included here]. See DOI: $10.1039 / \mathrm{x} 0 \mathrm{xx} 00000 \mathrm{x}$

I his journal Is (C) I he Royal society of chemıstry zUxx
}

regard, various substituted triamidoamine (TREN) frameworks have facilitated a wide range of unprecedented uranium chemistry. ${ }^{2}$ For example, the terminal $U \equiv N$ triple bond was prepared by reduction of $\left[\mathrm{U}^{\mathrm{IV}}\left(\mathrm{TREN}^{\mathrm{TPS}}\right)(\mathrm{Cl})\right]$ to $\left[\mathrm{U}^{\text {III }}\left(\mathrm{TREN}^{\mathrm{TPS}}\right)\right]$ (TREN ${ }^{\text {TIPS }}=$ $\left.\left\{\mathrm{N}\left(\mathrm{CH}_{2} \mathrm{CH}_{2} \mathrm{NSiPr}_{3}^{i}\right)_{3}\right\}^{3-}\right)$, followed by oxidation of an azide at a vacant $\mathrm{U}^{\text {III }}$ coordination site to form a uranium(V)-nitride; ${ }^{8}$ the latter could be oxidised to give the corresponding uranium(VI)-nitride. ${ }^{9}$ In a similar manner, a terminal uranium(V)-mono(oxo) species was prepared by oxidation of $\left[\mathrm{U}^{\text {III }}\left(\mathrm{TREN}^{\mathrm{TPS}}\right)\right]$ with $\mathrm{Me}_{3} \mathrm{NO}^{26}$ Nonreductive reactivity studies with [ $\left.\mathrm{U}^{\mathrm{IV}}\left(\mathrm{TREN}^{\mathrm{TPS}}\right)(\mathrm{Cl})\right]$ has given a range of parent terminal $\mathrm{U}=\mathrm{EH}(\mathrm{E}=\mathrm{N}, \mathrm{P}, \mathrm{As})$ groups, a $\mathrm{U}^{\mathrm{IV}} \equiv A \mathrm{~s}$ arsenide and trapping of $\mathrm{HAsAsH}$ and cyclo- $\mathrm{P}_{5}$, and more broadly low-valent [U(TREN)] complexes have facilitated isolation of the first uraniumdinitrogen complex and reductive homologation of carbon monoxide to ethyne diolate. ${ }^{13,14,27-31}$ If the metal-ligand multiplebond chemistry described above could be developed for transuranic elements it would greatly improve our knowledge and understanding of the electronic structure and reactivity of these elements.

Scheme 1 Synthesis of complexes 1 and $\mathbf{2}$.

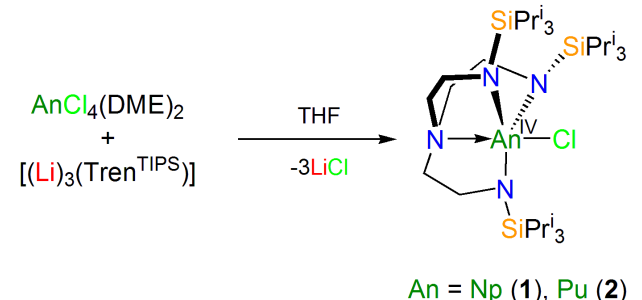

Herein, we report coordination of TREN ${ }^{\text {TIPS }}$ to neptunium(IV) and plutonium(IV) to afford $\left[\mathrm{An}^{\mathrm{IV}}\left(\operatorname{TREN}^{\mathrm{TPS}}\right)(\mathrm{Cl})\right](\mathrm{An}=\mathrm{Np}, 1 ; \mathrm{Pu}, 2)$. Moreover, NMR spectroscopy suggests that $\mathbf{1}$ and $\mathbf{2}$ can be reduced to putative [Np $\left.{ }^{\text {III }}\left(\operatorname{TREN}^{\mathrm{TPS}}\right)\right]$ and $\left[\mathrm{Pu}^{\prime \prime \prime}\left(\mathrm{TREN}^{\mathrm{TIPS}}\right)\right]$; complexes that provide a suitable platform for oxidative pathways to new metalligand multiple-bonds.

Dropwise treatment of $\left[\mathrm{AnCl}_{4}(\mathrm{DME})_{2}\right](\mathrm{An}=\mathrm{Np}, \mathrm{Pu})$, dissolved in cold THF, with one equivalent of $\left[(\mathrm{Li})_{3}\left(\right.\right.$ TREN $\left.\left.^{\text {TPS }}\right)\right]$, also dissolved in cold THF, results in salt metathesis and formation of $\mathbf{1}$ and $\mathbf{2}$, respectively (Scheme 1). Isolation of $\mathbf{1}$ and $\mathbf{2}$ from hexanes solution 
afforded crystalline yields of $51 \%$ and $19 \%$, respectively. The moderate, and low (but repeatable), rather than high isolated yields reflect the high product solubility on the small transuranic reaction scales. Single-crystals suitable for X-ray diffraction were grown from toluene/hexanes for $\mathbf{1}$ and hexanes for $\mathbf{2}$. The solid-state structures, Figure 1, reveal that $\mathbf{1}$ and $\mathbf{2}$ are isostructural to each other and also to the uranium(IV) congener. ${ }^{8}$ The actinide(IV) metal centres are five-coordinate, bound to three amide $\mathrm{N}$ atoms, one amine $\mathrm{N}$ atom, and a chloride anion completes the coordination sphere. The $\mathrm{Np}-$ $\mathrm{N}_{\text {amide }}$ distances in 1 range from 2.206(2) to 2.232(2) $\AA$, and are shorter (with some slight overlap) than the range of 2.231(2) to $2.255(2) \AA$ in the uranium(IV) congener. Since there is only one Np$\mathrm{N}_{\text {amine }}$ and one $\mathrm{Np}-\mathrm{Cl}$ distance, 2.605(2) and 2.6200(6) $\AA$, respectively, they can be compared directly to the corresponding uranium(IV) complex distances of 2.623(2) and 2.6383(6) $\AA$, with the conclusion that the neptunium bonds are slightly shorter as would be expected as a result of the actinide contraction. It is also noteworthy that $\mathbf{1}$ is the first structurally characterised neptunium(IV)-amide complex. The $\mathrm{Np}-\mathrm{Cl}$ distance is also consistent with $\mathrm{Np}^{\mathrm{IV}}-\mathrm{Cl}$ distances in the $\left[\mathrm{NpCl}_{4}(\mathrm{DME})_{2}\right]$ starting material, which range from $2.5877(9)$ to $2.6222(9) \AA .{ }^{32}$

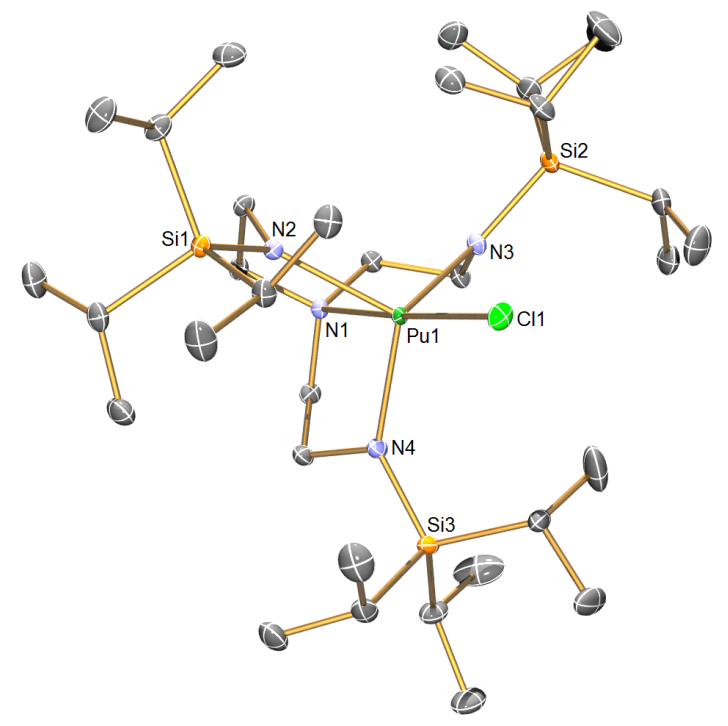

Fig 1 Thermal ellipsoid plot (at the 50\% probability level) of the solidstate structure of $\left[\mathrm{Pu}^{\mathrm{IV}}\left(\mathrm{TREN}^{\mathrm{TPS}}\right)(\mathrm{Cl})\right]$ (2). Hydrogen atoms are omitted for clarity. The neptunium analogue, $\mathbf{1}$, is isostructural (see ESI for details).

Table 1 Comparison of selected bond distances (Å) in $\left[\mathrm{An}^{\text {IV }}\left(\operatorname{TREN}^{\mathrm{TPS}}\right)(\mathrm{Cl})\right]$ complexes $\left(\mathrm{An}=\mathrm{Th}^{34} \mathrm{U}^{8}{ }^{8} \mathrm{~Np}(\mathbf{1}), \mathrm{Pu}(\mathbf{2})\right)$.

\begin{tabular}{|c|c|c|c|c|}
\hline & Th & U & $\mathrm{Np}$ & $\mathrm{Pu}$ \\
\hline $\mathrm{An}-\mathrm{Cl}$ & $2.693(2)$ & $2.6383(6)$ & $2.6200(6)$ & $2.6001(5)$ \\
\hline \multirow[t]{2}{*}{$\mathrm{An}-\mathrm{N}_{\text {amine }}$} & $2.668(3)$ & $2.623(2)$ & $2.605(2)$ & $2.577(2)$ \\
\hline & $2.284(3)$ & $2.231(2)$ & $2.2056(19)$ & $2.2122(17)$ \\
\hline \multirow[t]{2}{*}{$\mathrm{An}-\mathrm{N}_{\text {amido }}$} & $2.305(3)$ & $2.249(2)$ & $2.2305(19)$ & $2.2311(18)$ \\
\hline & $2.309(3)$ & $2.255(2)$ & $2.2322(19)$ & $2.2317(17)$ \\
\hline
\end{tabular}

Turning to the $\mathrm{Pu}^{\mathrm{IV}}$ complex, 2, the $\mathrm{Pu}-\mathrm{N}_{\text {amide }}$ distances range from $2.212(2)$ to $2.232(2) \AA$, and are indistinguishable from the corresponding values in $\mathbf{1}$. The only other $\mathrm{Pu}^{\mathrm{IV}}$-amide bond that has been structurally determined is in $\left[\mathrm{Pu}\left\{\mathrm{N}\left(\mathrm{SiMe}_{3}\right)_{2}\right\}_{3}(\mathrm{Cl})\right]$, with a value of 2.207(6) $\AA$ that is comparable to the range observed in $2 .{ }^{33}$ The Pu- $\mathrm{N}_{\text {amine }}$ distance of 2.577(2) $\AA$ and $\mathrm{Pu}-\mathrm{Cl}$ distance of 2.6001(5) $\AA$ are both slightly shorter than the values in $\mathbf{1}$, again reflecting the actinide contraction. The $\mathrm{Pu}-\mathrm{Cl}$ distance is also in the range of $2.5745(8)$ to $2.6033(8) \AA$ observed for $\mathrm{Pu}^{\mathrm{IV}}-\mathrm{Cl}$ distances in the $\left[\mathrm{PuCl}_{4}(\mathrm{DME})_{2}\right.$ ] precursor. ${ }^{32}$ The $\mathrm{Th}^{\mathrm{IV}}$ analogue, $\left[\mathrm{Th}^{\mathrm{IV}}\left(\mathrm{TREN}^{\mathrm{TPS}}\right)(\mathrm{Cl})\right]$, has been previously reported, ${ }^{34}$ meaning that isostructural complexes across the $\mathrm{An}^{\mathrm{IV}}$ series of $\mathrm{Th}, \mathrm{U}, \mathrm{Np}$, and $\mathrm{Pu}$ have been isolated and characterised - this is rare as few thorium and uranium studies are extended into the transuranic realm due to the specialist facilities required and also changes in redox stability from thorium to plutonium often impart difficulty in being able to isolate $\mathrm{Th}, \mathrm{U}, \mathrm{Np}$ and $\mathrm{Pu}$ in the same oxidation state in isostructural complexes. Table 1 (and ESI) provides a comparison of selected bond lengths demonstrating the general trend of shorter metalligand bond distances from left to right across the $5 f$ series that is consistent with predominately ionic bonds and the higher charge density of the $A n^{\mathrm{IV}}$ ions as the $5 \mathrm{f}$ series is traversed.

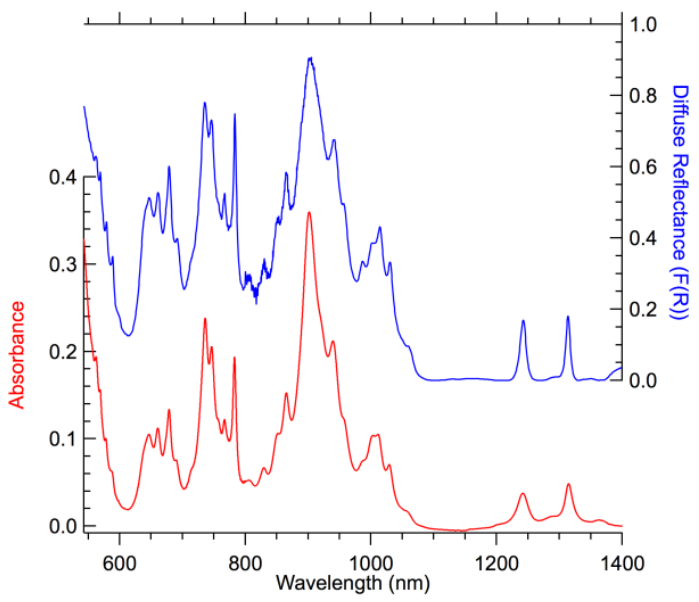

Fig 2 Vis-NIR diffuse reflectance spectrum of solid [Np $\left.{ }^{\text {IV }}\left(\operatorname{TREN}^{\text {TIPS }}\right)(\mathrm{Cl})\right]$ (1) (blue spectrum, right axis) and the solution spectrum of the solid dissolved in toluene (red spectrum, left axis) for comparison.

The ${ }^{1} \mathrm{H}$ NMR spectrum of crystalline 1 , dissolved in $\mathrm{C}_{6} \mathrm{D}_{6}$, reveals paramagnetically shifted resonances ( $\mathrm{Np}$ (IV) has a $5 f^{3}$ electronic configuration), that are readily assignable to $\mathrm{Pr}^{i}$ groups (7.71 and $6.27 \mathrm{ppm}$ ) and the two $\mathrm{CH}_{2}$ proton environments on the TREN arms (16.44 and $-32.15 \mathrm{ppm}$ ). Similarly, for $\mathbf{2}$, the same four resonances are observed at $1.14,0.11,9.84$, and $-1.18 \mathrm{ppm}$, respectively (Pu(IV) has a $5 f^{4}$ electronic configuration). The optical absorption spectra reveal a mixture of relatively narrow $5 f-5 f, 5 f-6 d$, and broader charge transfer bands. For $\mathbf{1}$, there is excellent correlation between the electronic transitions of the solution phase vis-NIR spectrum in hexanes and those in the solid-state, Figure 2, suggesting that the structure of $\mathbf{1}$ is maintained in solution (at least with a noncoordinating solvent). For $\mathbf{2}$, a very dark compound, the chargetransfer band extends past $800 \mathrm{~nm}$ and the solid-state spectrum is uninformative in the lower wavelength region; however, a correlation between the electronic transitions in the post-900 nm region is observed (see ESI) in terms of the profile, although the exact values do not match quite as closely as in $\mathbf{1}$. 
Initial reactivity studies of $\mathbf{1}$ with benzyl potassium suggest that the reaction is slower than the $\mathrm{Th}^{\mathrm{IV}}$ and $\mathrm{U}^{\mathrm{IV}}$ congeners, $^{34}$ possibly due to the increased steric encumbrance imparted by the TREN ${ }^{\text {TIPS }}$ ligand around the smaller $\mathrm{Np}^{\mathrm{IV}}$ ion. Therefore, consideration was given to attempting the same reaction with the more labile iodide anion in place of chloride. NMR spectroscopic data suggests that halide-exchange is achieved upon treatment of 1 with $\mathrm{Me}_{3} \mathrm{Si}-\mathrm{l}$ in toluene, although under these initial reaction conditions benzyl potassium appears to be essentially unreactive (see ESI). Resonances for 1 disappeared with the emergence of new peaks at 15.97, 10.10, 9.17, and $-37.75 \mathrm{ppm}$, tentatively assigned to $\left[\mathrm{Np}^{\mathrm{IV}}\left(\mathrm{TREN}^{\mathrm{TIPS}}\right)(\mathrm{I})\right]$, with integrals that correlate to the $\mathrm{CH}, \mathrm{CH}\left(\mathrm{CH}_{3}\right)_{2}$, $\mathrm{CH}\left(\mathrm{CH}_{3}\right)_{2}$ and $\mathrm{CH}$ protons, respectively. Although single-crystals of the iodide product were obtained, weak diffraction except at high angles prevented conclusive verification of the structure, and the possibility of a different reaction product cannot be entirely ruled out.

Stirring a hexanes solution of $\mathbf{1}$ or $\mathbf{2}$ over a potassium mirror for several days results in a colour change, formation of a colourless precipitate (presumed to be $\mathrm{KCl}$ ), suggestive of reduction of $\mathrm{An}^{\mathrm{IV}}$ to $A n^{\prime \prime \prime}$, and formation of [An ${ }^{\text {III }}\left(\right.$ TREN $\left.^{\text {TIPS }}\right)$ ] (Scheme 2), a product that is consistent with ${ }^{1} \mathrm{H}$ NMR spectroscopic data. In the case of $\mathbf{1}$, new resonances appear at 18.75, 18.11, 4.43 and 0.05 ppm, with integral values that match well for the $\mathrm{CH}, \mathrm{CH}, \mathrm{CH}\left(\mathrm{CH}_{3}\right)_{2}$ and $\mathrm{CH}\left(\mathrm{CH}_{3}\right)_{2}$ protons, respectively, in the presumed reduced $\mathrm{Np}^{\text {III }}$ complex. Only very minor resonances remain from $\mathbf{1}$. In the case of $\mathbf{2}$, the resonances corresponding to $\mathbf{2}$ disappear and new resonances emerge, which are attributed to a reduced $\mathrm{Pu}$ (III) complex, but the resonances are broad making specific assignments less clear cut than in the $\mathrm{Np}^{\text {III }}$ case (see ESI).
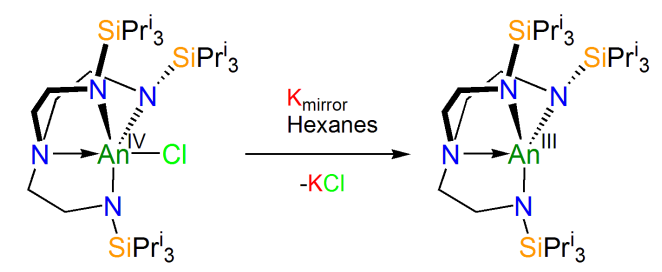

$A n=N p(1), P u(2)$

Scheme $\mathbf{2}$ Suggested reduction process for $\mathbf{1}$ and $\mathbf{2}$, yielding An(III) species.

In both cases, the very high solubility of the $A n^{\text {III }}$ derivatives even in non-coordinating solvents such as hexanes, $n$-pentane, and HMDSO (hexamethyldisiloxane), coupled with the relatively smallscales of transuranic reactions compared to uranium, has prevented isolation of pure crystalline products. Nonetheless, following filtration to remove the $\mathrm{KCl}$ by-product of the reduction process, it should be entirely feasible to conduct a wide range of in situ reactivity studies. For example, initial reactions of $\mathrm{Me}_{3} \mathrm{NO}$ and TEMPO (2,2,6,6-Tetramethylpiperidine 1-oxyl) with [Np ${ }^{\text {III }}\left(\operatorname{TREN}^{\text {TIPS }}\right)$ ] exhibit a distinct colour change, suggesting that oxidation occurs. Whether or not the product contains a terminal $\mathrm{Np}=\mathrm{O}$ or bridging $\mathrm{Np}-\mathrm{O}-\mathrm{Np}$ moiety is the subject of ongoing longer-term studies that are beyond a communication scope, given the non-trivial nature of small-scale transuranic synthetic chemistry.
In conclusion, we have demonstrated that even on the small scales required for safe and practicable handling of transuranics the TREN $^{\text {TIPS }}$ ligand can be installed on elements such as neptunium and plutonium to give actinide(IV)-chloride complexes. It appears that the chloride anion can be exchanged for the softer iodide or can be removed by reduction to afford trivalent derivatives. As well as providing rare non-aqueous transuranic molecules that present a rich seam of data through examination of their structural, spectroscopic, and reactivity properties, this work provides potentially important flexibility in subsequent syntheses and invaluable precursors for our currently ongoing pursuit of transuranic metal-ligand multiple-bond species.

J.L.B., A.J.G., and S.D.R. thank the U.S. Department of Energy, Office of Science, Early Career Research Program for funding the neptunium chemistry and initial plutonium chemistry. A.J.G. also thanks the U.S. Department of Energy, Office of Science, Basic Energy Sciences, Heavy Element Chemistry Program for funding completion of the plutonium chemistry and manuscript preparation. D.M.K., S.T.L., and A.J.W. thank the Royal Society, ERC, EPSRC, University of Nottingham, and University of Manchester for funding. We thank Mr Danil E. Smiles for assistance with unwrapping of multiply contained transuranic samples prior to transport to spectroscopic instrumentation and $\mathrm{Dr}$ Matthew S. Winston for providing an auxiliary sample of $\left[\left(\mathrm{Li}_{3}{ }_{3}\left(\mathrm{TREN}^{\mathrm{TIPS}}\right)\right]\right.$ ligand.

\section{Notes and references}

¥ Caution! ${ }^{237} \mathrm{~Np}$ and ${ }^{239} \mathrm{Pu}$ are high specific-activity $\alpha$-particle emitting radionuclides. This research was conducted in a radiological facility with appropriate analyses of hazards and implementation of controls to allow the safe handling and manipulation of radioactive materials. Experimental details concerning the reduction chemistry $\mathbf{1}$ and $\mathbf{2}$ along with other reactivity can be found in the ESI.

Synthesis of 1: THF $(1 \mathrm{~mL})$ was added to solid $\left[\mathrm{NpCl}_{4}(\mathrm{DME})_{2}\right]$ $(0.0430 \mathrm{~g}, 0.077 \mathrm{mmol})$ and cooled to $-35{ }^{\circ} \mathrm{C}$ in the drybox freezer. Separately, $\left[(\mathrm{Li})_{3}\left(\mathrm{TREN}^{\mathrm{TPS}}\right)\right](0.0487 \mathrm{~g}, 0.077 \mathrm{mmol})$ was dissolved in THF $(2 \mathrm{~mL})$ and cooled to $-35{ }^{\circ} \mathrm{C}$ in the drybox freezer. The cold ligand solution was added dropwise to the cold $\left[\mathrm{NpCl}_{4}(\mathrm{DME})_{2}\right] / \mathrm{THF}$ mixture over the course of $45 \mathrm{~min}$ (with a few seconds of stirring after each addition followed by placing back in the freezer for a few minutes to keep cold). During the addition process an orange solution was initially formed that became orange-red. The resultant solution was then stirred at ambient temperature for $16 \mathrm{~h}$ affording a deep orange-red solution. Volatiles were removed in vacuo and the oily residue dried in vacuo for $15 \mathrm{~min}$. The resulting solid residue was extracted into toluene $(3 \mathrm{~mL})$ at $50{ }^{\circ} \mathrm{C}$, allowed to cool to ambient temperature and filtered through a Celite pad supported by a glass fibre filter circle. The volume of the red filtrate was reduced in vacuo to $1 \mathrm{~mL}$ and stored at $-35^{\circ} \mathrm{C}$. After $2 \mathrm{~d}$ the red-orange microcrystalline solid that had deposited was collected and dried in vacuo. The supernatant was layered with HMDSO $(1 \mathrm{~mL})$ and a second crop of microcrystalline material was collected after $6 \mathrm{~d}$, and dried in vacuo and combined with the first crop to give a final orange-red powder of $1(0.0348 \mathrm{~g}$, $51 \%$ yield). Single-crystals suitable for $\mathrm{X}$-ray diffraction were obtained from a toluene/hexanes solution of $\mathbf{1}$ stored at $-35^{\circ} \mathrm{C}$. Vis/NIR of 1 dissolved in toluene (in $\mathrm{nm}$ ): 562, 569, 578, 587, $647,661,679,690$ (sh), 736, 746, 767, 783, 805, 829, 852(sh), 865, 902, 939, 957(sh), 989(sh), 1003, 1011, 1029, 1058(sh), 1241,1315 . Diffuse reflectance vis/NIR of solid 1 (in $\mathrm{nm}$ ): 562 , $569,579,589,647,661,679,691,736,747,767,784,805,830$, 
852(sh), 865, 902, 941, 957(sh), 987, 1002, 1014, 1030, 1060(sh) 1243, 1314. ${ }^{1} \mathrm{H}$ NMR (in $\mathrm{C}_{6} \mathrm{D}_{6}, 400 \mathrm{MHz}$ ): $\delta 7.71(\mathrm{~s}, 54 \mathrm{H}$, $\left.\mathrm{CH}\left(\mathrm{CH}_{3}\right)_{2}\right), 6.27\left(\mathrm{~s}, 9 \mathrm{H}, \mathrm{CH}\left(\mathrm{CH}_{3}\right)_{2}\right), 16.44\left(\mathrm{~s}, 6 \mathrm{H}, \mathrm{CH}_{2}\right),-32.15(\mathrm{~s}$, $6 \mathrm{H}, \mathrm{CH}_{2}$ ).

Synthesis of 2: Solid $\left[\mathrm{PuCl}_{4}(\mathrm{DME})_{2}\right](0.0413 \mathrm{~g}, 0.074 \mathrm{mmol})$ was cooled to $-35{ }^{\circ} \mathrm{C}$ in the drybox freezer. Separately, $\left[\left(\mathrm{Li}_{3}\right)\left(\right.\right.$ TREN $\left.\left.^{\text {TIPS }}\right)\right](0.0466 \mathrm{~g}, 0.074 \mathrm{mmol})$ was dissolved in THF (3 $\mathrm{mL}$ ) and cooled to $-35^{\circ} \mathrm{C}$ in the drybox freezer. The cold ligand solution was added to the Pu-containing solid resulting in the immediate formation of an intensely coloured solution, which was placed back in the freezer to cool back to $-35{ }^{\circ} \mathrm{C}$, and then stirred for $5 \mathrm{~min}$ then stored in the freezer for $16 \mathrm{~h}$ before being allowed to warm to ambient temperature with stirring over $2 \mathrm{~h}$. Volatiles were removed in vacuo, the residue triturated with hexanes $(3 \mathrm{~mL})$, and volatiles removed in vacuo. The residue was dissolved in hexanes $(3 \mathrm{~mL})$, filtered through Celite supported on a glass fibre filter circle, and the volume of the filtrate reduced in vacuo to $0.75 \mathrm{~mL}$. Following layering of the solution with HMDSO $(0.5 \mathrm{~mL})$ and storage at $-35{ }^{\circ} \mathrm{C}$ in the drybox freezer for 4 $\mathrm{d}$ the red crystalline material was collected and dried in vacuo ( $0.0122 \mathrm{~g}, 19 \%$ yield). Single-crystals suitable for X-ray diffraction were obtained from a hexanes solution of $\mathbf{2}$ stored at $-35^{\circ} \mathrm{C}$. $\mathrm{Vis} / \mathrm{NIR}$ of 2 dissolved in toluene (in $\mathrm{nm}$ ): 681, 690, 731, 741(sh), $850,942,1030,1065$ (sh), 1080, 1120, 1147, 1241. Diffuse reflectance vis/NIR of solid 2 (in nm): 945, 1032, 1063(sh), 1079, 1116(sh), 1147, 1230. ${ }^{1} \mathrm{H}$ NMR (in $\mathrm{C}_{6} \mathrm{D}_{6}, 400 \mathrm{MHz}$ ): $\delta 0.11$ (d, 54H, $\left.\mathrm{CH}\left(\mathrm{CH}_{3}\right)_{2}\right), 1.14\left(\mathrm{~s}, \mathrm{br}, 9 \mathrm{H}, \mathrm{CH}\left(\mathrm{CH}_{3}\right)_{2}\right), 9.84\left(\mathrm{~m}, 6 \mathrm{H}, \mathrm{CH}_{2}\right),-1.18(\mathrm{~m}$, $6 \mathrm{H}, \mathrm{CH}_{2}$ ).

§ Crystal data for 1: $\mathrm{C}_{33} \mathrm{H}_{75} \mathrm{ClN}_{4} \mathrm{NpSi}_{3}, M=884.69$, monoclinic, $a$ $=12.9845(10), b=15.6008(12), c=20.4035(15) \AA, \alpha=90.00, b=$ $90.648(1), v=90.00^{\circ}, V=4132.8(5) \AA^{3}, T=140(1) \mathrm{K}$, space group $P 2_{1} / \mathrm{n}, Z=4, \mu=2.692 \mathrm{~mm}^{-1}$, reflections collected/independent $=47211 / 9786\left(R_{\text {int }}=0.0391\right), R_{1}(I>2 \sigma(I))=0.0241$, and $w R_{2}(I>$ $2 \sigma(I))=0.0448$.

Crystal data for 2: $\mathrm{C}_{33} \mathrm{H}_{75} \mathrm{ClN}_{4} \mathrm{PuSi}_{3}, M=886.69$, monoclinic, $a$ $=13.0136(10), b=15.5458(12), c=20.4330(15) \AA, \alpha=90.00, b=$ 90.546(1), $v=90.00^{\circ}, V=4133.5(5) \AA^{3}, T=100(1) \mathrm{K}$, space group $P 2_{1} / \mathrm{n}, Z=4, \mu=1.772 \mathrm{~mm}^{-1}$, reflections collected/independent $=94248 / 17439\left(R_{\text {int }}=0.0250\right), R_{1}(I>2 \sigma(I))=0.0291$, and $w R_{2}(I>$ $2 \sigma(I))=0.0764$

1 M. B. Jones and A. J. Gaunt, Chem. Rev., 2013, 4, 1189.

2 B. M. Gardner and S. T. Liddle, Chem. Commun., 2015, 51 10589.

3 T. W. Hayton, Dalton Trans. 2010, 39, 1145.

4 T. W. Hayton, Chem. Commun., 2013, 49, 2956.

5 S. T. Liddle, Angew. Chem. Int. Ed., 2015, 54, 8604.

6 S. A. Johnson and S. C. Bart, Dalton Trans., 2015, 44, 7710.

7 H. S. La Pierre, K. Meyer, Prog. Inorg. Chem., 2014, 58, 303.

8 D. M. King, F. Tuna, E. J. L. McInnes, J. McMaster, W. Lewis, A. J. Blake and S. T. Liddle, Science, 2012, 337, 717.

9 D. M. King, F. Tuna, E. J. L. Mclnnes, J. McMaster, W. Lewis, A. J. Blake and S. T. Liddle, Nat. Chem., 2013, 5, 482.

10 P. A. Cleaves, D. M. King, C. E. Kefalidis, L. Maron, F. Tuna, E. J. L. Mclnnes, J. McMaster, W. Lewis, A. J. Blake, S. T. Liddle, Angew. Chem. Int. Ed., 2014, 53, 10412.

11 T. W. Hayton, J. M. Boncella, B. L. Scott, P. D. Palmer, E. R. Batista and P. J. Hay, Science, 2005, 310, 1941.

$12 \mathrm{~N}$. H. Anderson, S. O. Odoh, Y. Yao, U. J. Williams, B. A. Schaefer, J. J. Kiernicki, A. J. Lewis, M. D. Goshert, P. E. Fanwick, E. J. Schelter, J. R. Walensky, L. Gagliardi and S. C. Bart, Nat. Chem., 2014, 6, 919.

13 B. M. Gardner, G. Balázs, M. Scheer, F. Tuna, E. J. L. McInnes, J. McMaster, W. Lewis, A. J. Blake and S. T. Liddle, Angew. Chem. Int. Ed., 2014, 53, 4484.
14 B. M. Gardner, G. Balázs, M. Scheer, F. Tuna, E. J. L. McInnes, J. McMaster, W. Lewis, A. J. Blake and S. T. Liddle, Nat. Chem., 2015, 7, 582.

15 D. E. Smiles, G. Wu, N. Kaltsoyannis and T. W. Hayton, Chem. Sci., 2015, 6, 3891.

16 D. E. Smiles, G. Wu and T. W. Hayton, Inorg. Chem., 2014, 53, 10240.

17 D. E. Smiles, G. Wu and T. W. Hayton, J. Am. Chem. Soc., 2014, 136, 96.

18 J. L. Brown, S. Fortier, G. Wu, N. Kaltsoyannis and T. W. Hayton, J. Am. Chem. Soc., 2013, 135, 5352.

19 J. L. Brown, S. Fortier, R. A. Lewis, G. Wu and T. W. Hayton, J. Am. Chem. Soc., 2012, 134, 15468.

20 M. B. Jones, A. J. Gaunt, J. C. Gordon, N. Kaltsoyannis, M. P. Neu and B. L. Scott, Chem. Sci., 2013, 4, 1189.

21 A. J. Gaunt, S. D. Reilly, A. E. Enriquez, B. L. Scott, J. A. Ibers, P. Sekar, K. I. M. Ingram, N. Kaltsoyannis, and M. P. Neu, Inorg. Chem., 2008, 47, 29.

22 D. D. Schnaars, E. R. Batista, A. J. Gaunt, T. W. Hayton, I. May, S. D. Reilly, B. L. Scott, and G. Wu, Chem. Commun., 2011, 47, 7647.

23 J. A. Macor, J. L. Brown, J. N. Cross, S. R. Daly, A. J. Gaunt, G. S. Girolami, M. T. Janicke, S. A. Kozimor, M. P. Neu, A. C. Olson, S. D. Reilly, and B. L. Scott, Dalton Trans., 2015, 44, 18923.

24 A. J. Gaunt and M. P. Neu, C. R. Chim., 2010, 13, 821.

25 J. L. Brown, E. R. Batista, J. M. Boncella, A. J. Gaunt, S. D. Reilly, B. L. Scott and N. C. Tomson, J. Am. Chem. Soc., 2015, $137,9583$.

26 D. M. King, F. Tuna, J. McMaster, W. Lewis, A. J. Blake, E. J. L. McInnes and S. T. Liddle, Angew. Chem. Int. Ed., 2013, 52, 4921.

27 D. M. King, J. McMaster, F. Tuna, E. J. L. Mclnnes, W. Lewis, A. J. Blake, and S. T. Liddle, J. Am. Chem. Soc., 2014, 136, 5619.

28 P. Roussel and P. Scott, J. Am. Chem. Soc., 1998, 120, 1070.

29 B. M. Gardner, J. C. Stewart, A. L. Davis, J. McMaster, A. J. Blake and S. T. Liddle, Proc. Natl. Acad. Sci., 2012, 109, 9265.

30 B. M. Gardner, G. Balázs, M. Scheer, A. J. Wooles, F. Tuna, E. J. L. McInnes, J. McMaster, W. Lewis, A. J. Blake and S. T. Liddle, Angew. Chem. Int. Ed., 2015, 54, 15250.

31 B. M. Gardner, F. Tuna, E. J. L. Mclnnes, J. McMaster, W. Lewis, A. J. Blake, and S. T. Liddle, Angew. Chem. Int. Ed., 2015, 54, 7068.

32 S. D. Reilly, J. L. Brown, B. L. Scott and A. J. Gaunt, Dalton Trans., 2014, 43, 1498.

33 A. J. Gaunt, S. D. Reilly, A. E. Enriquez, T. W. Hayton, J. M. Boncella, B. L. Scott and M. P. Neu, Inorg. Chem., 2008, 47, 8412.

34 B. M. Gardner, P. A. Cleaves, C. E. Kefalidis, J. Fang, L. Maron, W. Lewis, A. J. Blake and S. T. Liddle, Chem. Sci., 2014, 5, 2489. 